\title{
DE NIEUWJAARSDAG VAN 1807
}

DOOR

\section{B. DE GAay Fortman}

In den 25sten jaargang van dit tijdschrift (1923), bladz. 193 e.v.) is een opstel van mijn hand verschenen over de verrassing van Curaçao in den vroegen morgen van 1 Januari 1807 . Daarbij zijn opgenomen twee kaartjes, van den havenmond en de fortres op den rechteroever, waarop de aanval plaats had, met omgeving. Deze kaartjes zijn geteekend door wijlen den heer Kesler, maar geheel volgens mijn aanwijzingen, die ik zooveel mogelijk ontleend had aan oude kaarten en mededeelingen uit dien tijd in de geraadpleegde stukken.

Ik ontving onlangs een brief van den heer N. van Meeteren op Curaçao, kenner bij uitnemendheid van dit tijdvak der geschiedenis van het eiland, die verschillende onjuistheden op beide kaartjes aanwijst. Het lijkt mij van belang om deze hier mee te deelen.

De heer Van Meeteren dan schrijft: „De batterijen of wallen, beoosten de stad geteekend, hebben nooit bestaan. Het plan van Schrijver c.s. is nooit ten uitvoer gebracht. Ten zuiden van het fort Amsterdam lagen twee batterijen of bolwerken, te weten meer naar het westen het Nieuwe Waterfort en ten oosten daarvan het Oude Waterfort. Waar de batterij de Halve Maan stond, valt met zekerheid niet te zeggen. Zij maakte een deel uit van het fort Amsterdam, of lag buiten het fort, maar dan niet ver van de batterij verwijderd. In allen gevalle niet op de plaats, op kaart I onder 7 aangegeven, waar zich het Militair hospitaal en een paar huizen bevonden, tot tegen den kerkhofmuur.... Op de plaats, aangeduid met 8, lag de batterij de Krommelijn. De vlaggestok stond eerst op het bolwerk van dienzelfden naam, aangeduid op kaart II met 8, kruitmagazijn. Onder Lauffer werd die echter verplaatst naar het N.O. bastion (De Katte). 
De werf van Basden lag veel zuidelijker dan aangegeven (tegenwoordige Westwerf van de K.N.S.M.).

De cijfers 24 en 25 moeten onderling verwisseld worden.

Op kaart II moet 12 luiden Mil. Hosp. en kazerne en 13 Pietermaai. De Krommelijn leunde tegen den kerkhofmuur aan. Waar men op het kaartje de Krommelijn vindt aangegeven stonden reeds in 1788 twee huizen, waarvan één het eigendom was van Jacob de Petersen en het andere van Wilhelmina de Peek. In 1834 stonden die huizen er nog; zij behoorden toe aan Hendrik Hommels en Adrianus Propheet".

Tot zoover de opmerkingen van den heer Van Meeteren, die een welkome verbetering zijn van het door mij gegevene. Ik zeg hem daarvoor zeer dank.

Amsterdam 16 Juni 1945 